\title{
Correction to: A pilot study of improved psychological distress with art therapy in patients with cancer undergoing chemotherapy
}

\author{
E. B. Elimimian ${ }^{1}$, L. Elson ${ }^{1}$, E. Stone ${ }^{1}$, R. S. Butler ${ }^{2}$, M. Doll', S. Roshon ${ }^{1}$, C. Kondaki ${ }^{1}$, A. Padgett ${ }^{3}$ and Z. A. Nahleh ${ }^{1 *}$
}

\section{Correction to: BMC Cancer 20, 899 (2020) \\ https://doi.org/10.1186/s12885-020-07380-5}

Following publication of the original article [1], the authors report the following error in the third paragraph of the discussion section. Mandala coloring is not a primary modality used in art therapy, nor was it a primary modality used in the intervention of this study. The first sentence of this paragraph should therefore read "Our data suggests that introspective Mandala drawings, one type of art modality utilized for art therapy, is beneficial."

\section{Author details \\ 'Department of Hematology/Oncology, Maroone Cancer Center, Cleveland Clinic - Florida, 2950 Cleveland Clinic Blvd, Weston, FL 33331, USA. 2Department of Radiation Oncology, Dana-Farber Cancer Institute/ Brigham and Women's Hospital, 75 Francis St, Boston, MA 02115, USA. ${ }^{3}$ Charles E. Schmidt College of Medicine, Florida Atlantic University, 777 Glades Road BC-71, Boca Raton, FL 33431, USA.}

Published online: 20 November 2020

\section{Reference}

1. Elimimian $E B$, Elson L, Stone $E$, et al. A pilot study of improved psychological distress with art therapy in patients with cancer undergoing chemotherapy. BMC Cancer. 2020;20:899 https://doi.org/10.1186/s12885020-07380-5.

The original article can be found online at https://doi.org/10.1186/s12885020-07380-5

* Correspondence: nahlehz@ccf.org

'Department of Hematology/Oncology, Maroone Cancer Center, Cleveland Clinic - Florida, 2950 Cleveland Clinic Blvd, Weston, FL 33331, USA

Full list of author information is available at the end of the article

(c) The Author(s). 2020 Open Access This article is licensed under a Creative Commons Attribution 4.0 International License, which permits use, sharing, adaptation, distribution and reproduction in any medium or format, as long as you give appropriate credit to the original author(s) and the source, provide a link to the Creative Commons licence, and indicate if changes were made. The images or other third party material in this article are included in the article's Creative Commons licence, unless indicated otherwise in a credit line to the material. If material is not included in the article's Creative Commons licence and your intended use is not permitted by statutory regulation or exceeds the permitted use, you will need to obtain permission directly from the copyright holder. To view a copy of this licence, visit http://creativecommons.org/licenses/by/4.0/ The Creative Commons Public Domain Dedication waiver (http://creativecommons.org/publicdomain/zero/1.0/) applies to the data made available in this article, unless otherwise stated in a credit line to the data. 